\title{
Behavior of individual mesopelagic fish in acoustic scattering layers of Norwegian fjords
}

\author{
Stein Kaartvedt ${ }^{1, *}$, Thomas Torgersen ${ }^{2,4}{ }^{\text {, Thor A. Klevjer }}{ }^{1}$, Anders Røstad ${ }^{1}$, \\ Jennifer A. Devine ${ }^{3,5}$ \\ ${ }^{1}$ Department of Biology, University of Oslo, PO Box 1066 Blindern, 0316 Oslo, Norway \\ ${ }^{2}$ Department of Biology, University of Bergen, 5020 Bergen, Norway \\ ${ }^{3}$ Department of Biology, Memorial University, St. John's, Newfoundland A1C 5S7, Canada \\ ${ }^{4}$ Present address: Institute of Marine Research, PO Box 1870 Nordnes, 5817 Bergen, Norway \\ ${ }^{5}$ Present address: National Institute of Water and Atmospheric Research Ltd., Private Bag 14-901, Kilbirnie, Wellington, \\ New Zealand
}

\begin{abstract}
Mesopelagic acoustic scattering layers (SLs) in 2 fjords were studied from a stationary research vessel. Diel vertical movements of SLs were assessed by hull-mounted transducers, while in situ behavior of individuals constituting the SLs was resolved by a submerged echo sounder. The study focused on SLs made up of the lightfish Maurolicus muelleri and the lanternfish Benthosema glaciale. Individual fish migrated in a pronounced stepwise manner, alternating between vertical movements and stationary phases both during ascent and descent. Mean lengths of steps varied between 2.01 and $0.40 \mathrm{~m}$, and mean duration of stationary phases between 69 and $36 \mathrm{~s}$ for fish in different SLs. Such travel-pause behavior concords with saltatory search, where fish scan the water for prey during the stationary phases, relocate and scan a new water parcel. Little activity was recorded among individuals in deep water, apart from infrequent, short shifts in vertical distribution. This study shows that stationary submerged echo sounders can provide detailed information on in situ behavior of mesopelagic fish.
\end{abstract}

KEY WORDS: Benthosema glaciale $\cdot$ Maurolicus muelleri $\cdot$ Diel vertical migration $\cdot$ Saltatory search · Acoustics $\cdot$ Fjords

Resale or republication not permitted without written consent of the publisher

\section{INTRODUCTION}

Mesopelagic acoustic scattering layers (SLs) occur almost ubiquitously in the world's oceans (Garrison 2005). Their components vary, but SLs are often dominated by small fish, occurring together with krill, shrimps and larger predators (Giske et al. 1990, Hopkins \& Sutton 1998). In the North Atlantic, potential predatory impact by mesopelagic planktivores on copepods overwintering in deep waters (Calanus spp.) has been of special interest in recent years (Dale et al. 1999, Kaartvedt 2000, Bagøien et al. 2001, Anderson et al. 2005). Diel migrating mesopelagic fish also harvest plankton from upper layers (e.g. Pearre 2003). Thus, in ecosystems like the Norwegian Sea, mesopelagic fish share the secondary production with planktivores that traverse the ocean on seasonal feeding migrations, such as herring and mackerel. In marine ecosystems that do not sustain large stocks of horizontally migratory fish, mesopelagic fish may be the prevailing consumers of the secondary production (e.g. Smith et al. 1998). The mesopelagic fauna also represent prominent prey for higher trophic levels (Benoit-Bird 2004, Skjoldal 2004).

The importance of the mesopelagic fauna in marine ecosystems underlines the need to understand the mechanics of their trophic interactions. This requires knowledge of individual behavior, since activity levels and swimming patterns determine interactions between prey and predators (Gerritsen \& Strickler 1977, O'Brien et al. 1990). However, a lack of appropriate methods has hampered such work, until now. Apart from some observations made from submersibles and remotely operated vehicles (ROVs) (e.g. Barham 1966, Janssen et al. 1986, Auster et al. 1992, Robison 2004), little information exists on the swimming behavior of mesopelagic fish and other components of the mesopelagic fauna. 
Most studies on acoustic SLs using conventional echo sounders are carried out from moving vessels. However, if the vessel (echo sounder) is kept stationary, echo sounders can be used to study the movements of individuals constituting the SLs (Torgersen \& Kaartvedt 2001, Klevjer \& Kaartvedt 2003, 2006). Using submerged echo sounders, it is possible to resolve the swimming behavior of individuals in situ (Klevjer \& Kaartvedt 2003, 2006, Onsrud et al. 2005), even in deep water. Norwegian fjords are deep and their faunal composition resembles that of the adjacent ocean; therefore, fjords can be used as easily accessible ocean models. The typically calm waters in sheltered fjord environments compared to the open sea imply a reduction of ship and transducer movements, as well as low advection of acoustic targets. Conditions are therefore ideal for exploiting acoustic techniques to study individual swimming behavior of mesopelagic organisms in situ.

In this study, we assessed the potential of using stationary, submerged echo sounders in observing the behavior of individuals in mesopelagic SLs. We addressed diel vertical migration (DVM) and activity patterns, and demonstrated that this approach reveals detailed information on in situ behavior of mesopelagic fish.

\section{MATERIALS AND METHODS}

The study was carried out from 5 to 12 November 2004 in the deepest part of Masfjorden $\left(60^{\circ} 5^{\prime} \mathrm{N}, 5^{\circ} 2^{\prime} \mathrm{E}\right)$ and Sørfjorden $\left(60^{\circ} 3^{\prime} \mathrm{N}, 5^{\circ} 4^{\prime} \mathrm{E}\right)$, Norway, at the same locations depicted in Bagøien et al. (2001). Due to unusually strong winds, the station in Sørfjorden was shifted on the second day. Masfjorden has a maximum depth of $\sim 490 \mathrm{~m}$ and is separated from outer waters by a $\sim 75 \mathrm{~m}$ deep sill. The maximum depth of Sørfjorden is $\sim 380 \mathrm{~m}$. This fjord is open in both ends, and its deepest connection to outer waters is $\sim 90 \mathrm{~m}$. The sky was overcast throughout the period. The moon was half and waning at the start of the study. Wind speeds were $<10$ knots and wave heights $\sim 25 \mathrm{~cm}$ most of the time in Masfjorden. In Sørfjorden, wind speeds reached 23 knots with wave heights of $\sim 1 \mathrm{~m}$ during the last day.

Hull-mounted SIMRAD EK500 echo sounders, at $18 \mathrm{kHz}\left(11^{\circ}\right.$ beam width) and $38 \mathrm{kHz}$ ( $7^{\circ}$ beam width), were used in combination with a submerged, $120 \mathrm{kHz}$ EK60 echo sounder ( $7^{\circ}$ beam width). We took advantage of different acoustic properties at different frequencies in identification of targets. The wavelength is $1.3 \mathrm{~cm}$ at $120 \mathrm{kHz}, 3.9 \mathrm{~cm}$ at $38 \mathrm{kHz}$ and $8.3 \mathrm{~cm}$ at $18 \mathrm{kHz}$, roughly defining the respective minimum sizes of individuals being detected. Most of the behavioral observations were at $120 \mathrm{kHz}$, but since similar individual behavior also was recorded at $38 \mathrm{kHz}$ for the targets focused on here, we ascribe these targets to mesopelagic fish rather than co-occurring invertebrates. SLs composed of many smaller organisms can be recorded at lower frequencies than single individuals, but at $18 \mathrm{kHz}$, even dense assemblages of most invertebrates will not be detected. Scattering from the swimbladders of mesopelagic fishes (swimbladder resonance) is the predominant cause of acoustic reverberation at this frequency (Love et al. 2004). The SLs focused on here were also recorded at $18 \mathrm{kHz}$ and accordingly were allocated to fish.

The submerged echo sounder was placed in a pressure casing. It was powered through $300 \mathrm{~m}$ of cable, which also transferred digital data back to the ship. This echo sounder was deployed at various depths to obtain high resolution information on individual targets in deeper layers. At some depths, a calibration sphere was attached to check that performance did not change with pressure. All external lights on the ship were turned off during the acoustic sampling, except for short periods when adjusting the depth of the submerged echo sounder. There was a depth limitation of $150 \mathrm{~m}$ for this particular pressure casing. Acoustic raw data were stored for later analysis, except for $18 \mathrm{kHz}$ in Masfjorden where only pixel data were available. Echograms were visualized in Matlab, and post-processing of data was done with Sonar5 software (Balk \& Lindem 2002).

The RV 'Håkon Mosby' was kept stationary by means of automatic satellite navigation (dynamic positioning) during most of the acoustic recordings. This procedure made it possible to follow individual targets for extended periods (over many 'pings') in this low-advection environment. The behavior of individuals was derived from echo traces on echograms and from acoustic target tracking (TT). Split-beam echo sounders can determine both horizontal and vertical positions of a target in the acoustic beam (e.g. Ehrenberg \& Torkelson 1996), and TT can be used to establish swimming trajectories through the acoustic beam by applying algorithms allocating subsequent echoes to the same target (Balk \& Lindem 2002). Data on target strength (TS), a proxy for size, were also provided. We applied TT in assessing individual vertical swimming patterns, using echoes generated with the cross-filter detector in Sonar5 (Balk \& Lindem 2000). Echoes were manually assigned to tracks based on visual examination of echograms. We defined 3 states of behavior: upwards swimming, pause and downwards swimming. The boundaries between these states were set to $\pm 2 \mathrm{~cm} \mathrm{~s}^{-1}$ (ping to ping vertical speeds smoothed with a 20 point wide running mean, 10 points for the dawn rise data). Segments with TS in the range -68 to $-55 \mathrm{~dB}$ were accepted as mesopelagic fish.

We planned to use a Harstad trawl with a multisampler opening/closing cod-end (permitting depth stratified sampling) for capturing the mesopelagic fauna, but the 
trawl with the multisampler did not function properly. The sampling in Masfjorden was therefore restricted to oblique tows, which provided qualitative information on the faunal composition of the integrated water column. This trawling unveiled a mixture of the lightfish Maurolicus muelleri and the lanternfish Benthosema glaciale, which is in accordance with results from numerous previous studies in Masfjorden (Kaartvedt et al. 1988, Giske et al. 1990, Baliño \& Aksnes 1993, Bagøien et al. 2001). The sampling approach was changed in the second fjord, Sørfjorden. Macroplankton and mesopelagic fish were sampled with a ring net (Munk et al. 1995) with a 2 m opening diameter, $500 \mu \mathrm{m}$ mesh size and $\sim 12 \mathrm{~m}$ length. A total of 15 tows were made day and night. The net was towed at 2.5 knots in hauls covering various depth intervals (Table 1), monitored during sampling by a Scanmar depth sensor. The net did not contain a closing mechanism, and ship speed was minimized to reduce contamination from shallower strata during launching and retrieval of the net.

\section{RESULTS}

\section{Catches in Sørfjorden}

Maurolicus muelleri and Benthosema glaciale were captured regularly in the net. M. muelleri was mainly captured above $75 \mathrm{~m}$, with catches dominated by small specimens (juveniles; Fig. 1). B. glaciale stayed deeper than $125 \mathrm{~m}$ in the daytime. The smallest individuals were then captured in the shallowest interval, while the largest individuals were captured below $175 \mathrm{~m}$ (Fig. 1). Both species carried out DVM.

The most abundant species of macroplankton in the samples were the krill Meganyctiphanes norvegica, the shrimp Sergestes arcticus and the mysid Boreomysis arctica.

\section{Distribution of SLs}

A distinct, vertically migrating SL was present in the upper part of the water column. In Masfjorden, the SL was located between $\sim 75$ and $100 \mathrm{~m}$ in the daytime, while it occurred $\sim 25 \mathrm{~m}$ shallower in Sørfjorden (Fig. 2). This SL migrated towards the surface at dusk, with a subsequent descent, establishing a nocturnal SL down to $\sim 60 \mathrm{~m}$ (both fjords). A dawn ascent preceded the descent in the morning.
Masfjorden was characterized by a second layer located between $\sim 150$ and $250 \mathrm{~m}$ both day and night. DVM was apparent as a flux of targets descending into this mid-water SL in the morning and ascending out of the layer in the evening. In Sørfjorden, DVM in mid-waters comprised a stronger 'core' embedded in a weaker SL, the core descending to $\sim 200 \mathrm{~m}$ in the daytime (Fig. 2).

\section{Behavior of individuals}

Masfjorden

The submerged $120 \mathrm{kHz}$ echo sounder provided closeup information on individuals during their DVM. Fish ascending from and descending into the mid-water SL migrated in a stepwise (stop-and-go) manner, so that their echo traces displayed a staircase pattern both dur-

Table 1. Sampling by ring net in Sørfjorden on 10 to 12 November 2004

\begin{tabular}{|c|c|c|c|}
\hline \multirow{2}{*}{$\overline{\text { Time }}^{\mathrm{Nigl}}$} & \multirow{2}{*}{$\overline{\text { Depth (m) }}$} & \multirow[b]{2}{*}{ Time } & \multirow{2}{*}{$\overline{\text { Depth }(\mathrm{m})}$} \\
\hline & & & \\
\hline 03:06-03:38 & $20-10$ & & \\
\hline 00:01-00:31 & $57-35$ & & \\
\hline $22: 10-22: 40$ & $79-61$ & $13: 30-14: 00$ & $78-62$ \\
\hline $02: 27-02: 57$ & $105-80$ & & \\
\hline $01: 43-02: 13$ & $125-100$ & $14: 20-14: 50$ & $117-85$ \\
\hline $23: 07-23: 31$ & $137-120$ & $14: 15-14: 45$ & $135-126$ \\
\hline 00:53-01:25 & $174-135$ & $12: 07-12: 37$ & $160-140$ \\
\hline $21: 15-21: 45$ & $210-180$ & $12: 40-13: 10$ & $215-175$ \\
\hline $02: 45-03: 30$ & $360-240$ & $13: 11-13: 43$ & $372-240$ \\
\hline
\end{tabular}
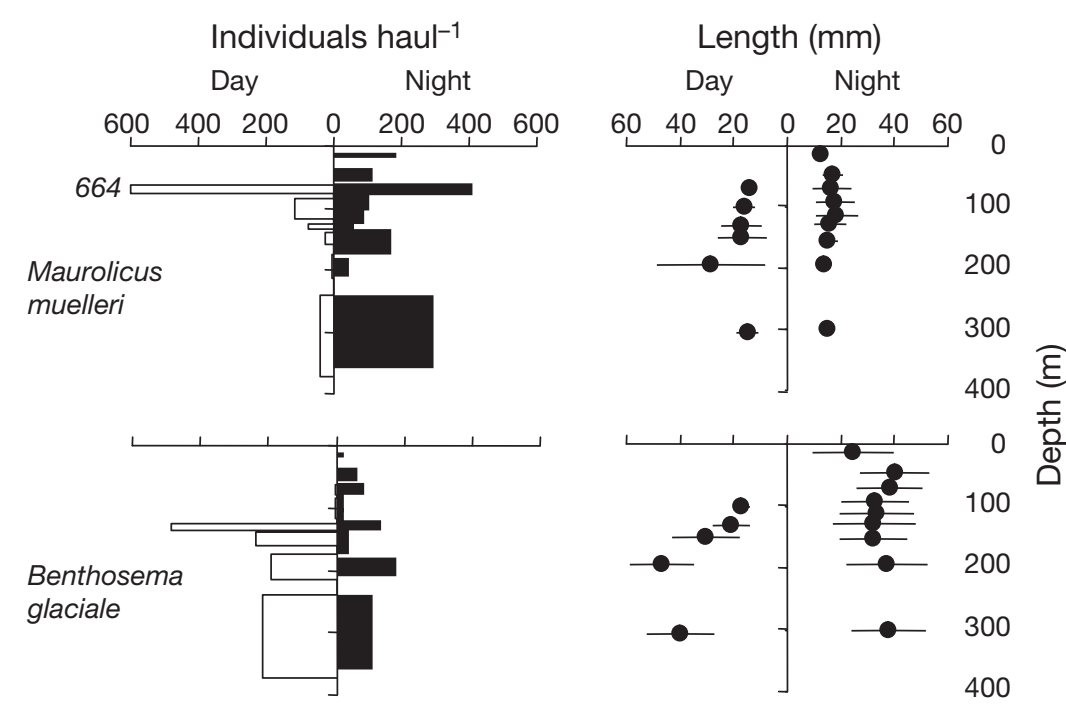

Fig. 1. Maurolicus muelleri and Benthosema glaciale. Catches (by ring net) of fish in Sørfjorden. Number of individuals per $30 \mathrm{~min}$ tow and average length \pm 1 SD (standard length) are shown 

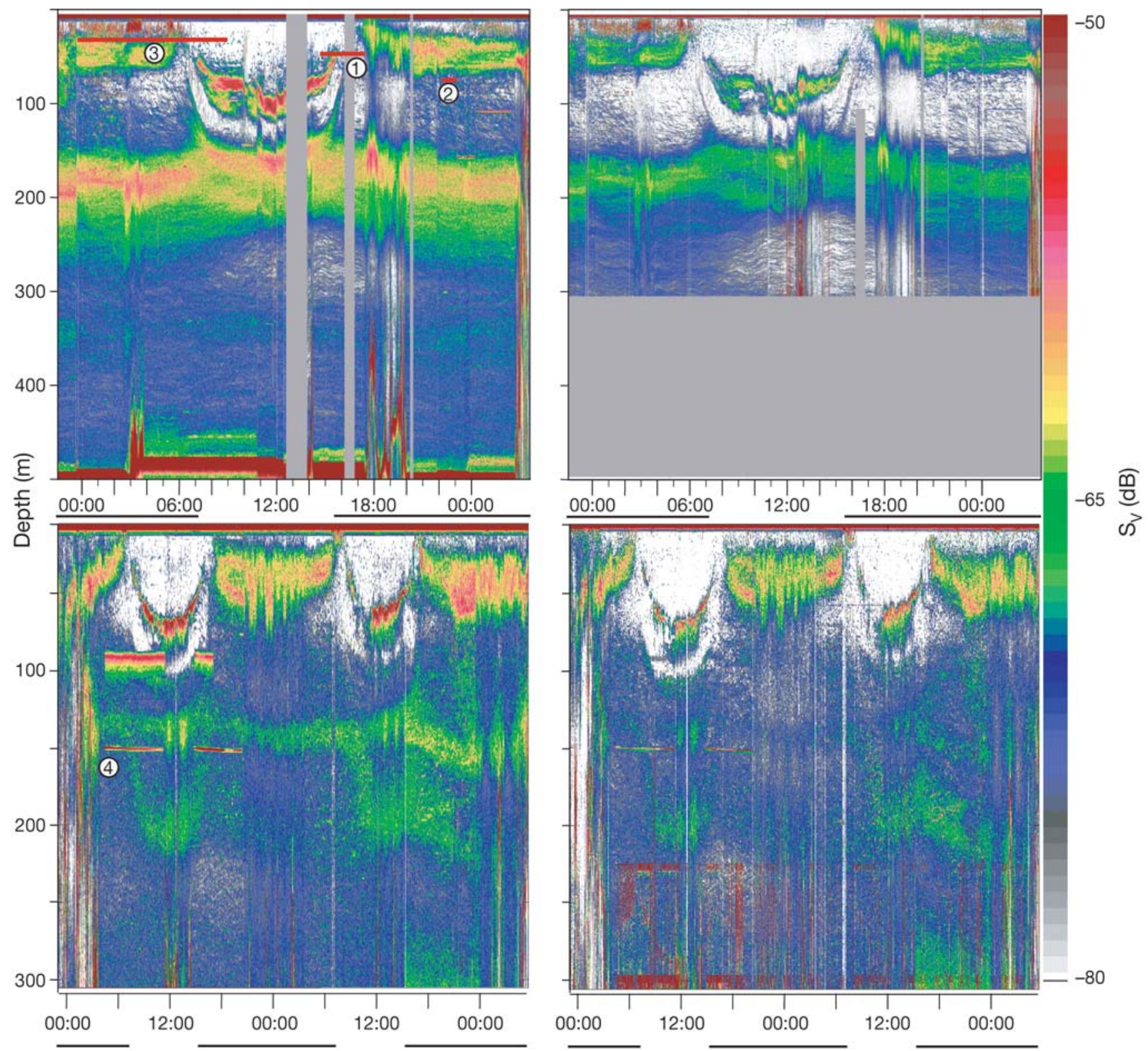

\section{Time (GMT)}

Fig. 2. Echogram from the 18 (left-hand panels) and $38 \mathrm{kHz}$ (right-hand panels) hull-mounted transducer in Masfjorden 5 to 7 November (upper panels) and Sørfjorden 9 to 12 November (lower panels). The submerged echo sounder is marked as a horizontal line, and when denoted by numbers refers to events identified in Figs. 3, 6 \& 7. Color scale refers to volume backscattering $\left(\mathrm{S}_{\mathrm{v}}\right)$, with gray representing the weakest and reddish-brown the strongest echoes. Periods between sunset and sunrise are marked by a horizontal black line

ing ascent and descent (Fig. 3). The length of steps and duration of stationary phases varied, with $2.01 \pm 1.39 \mathrm{~m}$ and $42 \pm 32 \mathrm{~s}($ mean $\pm \mathrm{SD})$, respectively during the ascent phase $\left(\mathrm{n}_{\text {tracks }}=36\right)$. The diel migrating individuals remained in the acoustic beam for prolonged periods, as seen in the long-lasting individual echo traces (Figs. 3 \& 4). TT showed that targets remained even within a very limited sector $\left(\mathrm{a}\right.$ few $\left.\mathrm{m}^{2}\right)$ of the beam while migrating tens of meters vertically (Fig. 4).
In the afternoon, records of stepwise ascending individuals (Fig. 3a) continued for $\sim 1 \mathrm{~h}$, immediately followed by the first records of stepwise descent. Concurrent with this early descent, other targets (not identified here) were ascending. These were prone to more directly upward swimming, interrupted by short stationary phases (Fig. 3b). During the first part of the night, both stepwise descending and ascending targets were recorded (Fig. 3c). There was an increasing pre- 

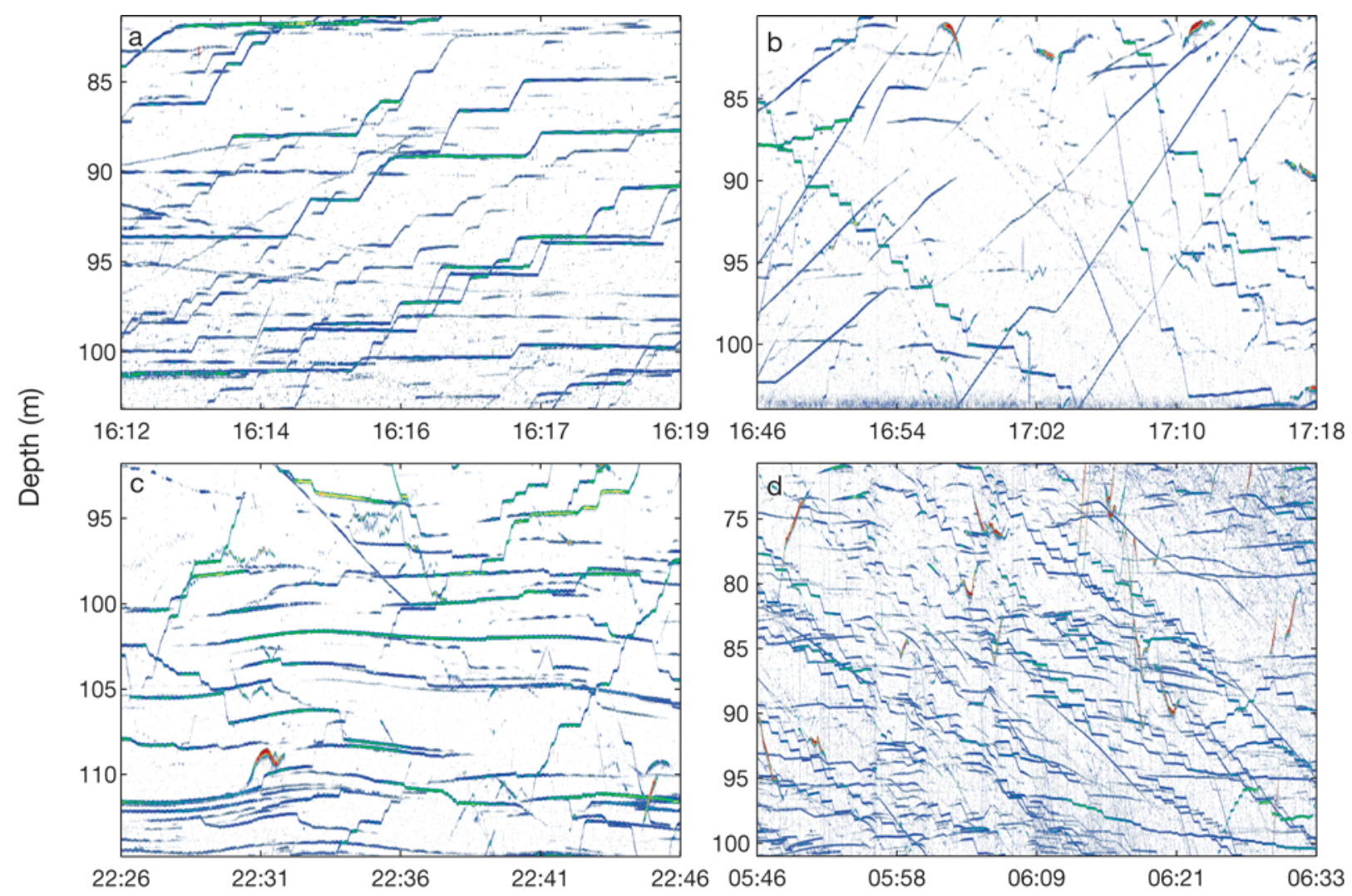

Time

Fig. 3. Vertically migrating individuals in Masfjorden as recorded from a submerged $120 \mathrm{kHz}$ echo sounder during different parts of the diel migration cycle. Each 'line' is the echo trace of 1 individual. (a) Ascent, (b) first signs of stepwise descent in the afternoon, (c) middle of the night and (d) late at night. $\mathrm{S}_{\mathrm{v}}$ threshold is $-85 \mathrm{~dB}$. The submerged echo sounder is depicted in Fig. 2 by \#1 for records in (a) and (b), \#2 for records in (c) and \#3 for records in (d). Sunset at 15:30 h, sunrise at 07:15 h. Time is GMT (local - $1 \mathrm{~h}$ )
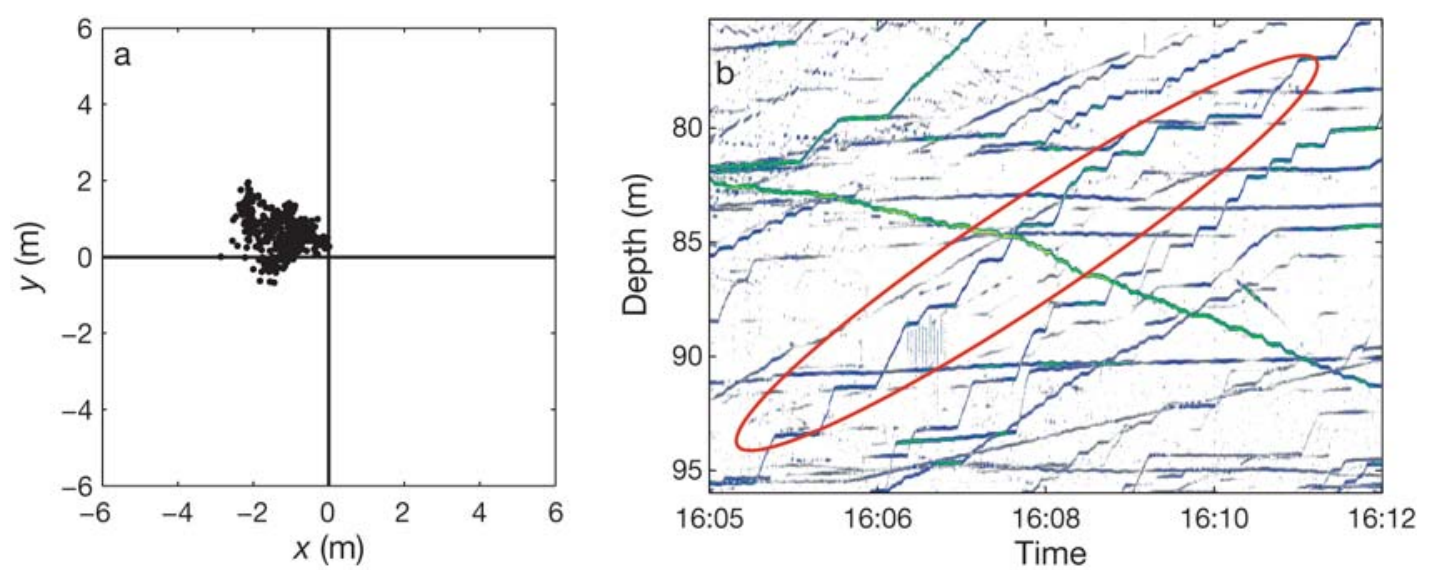

Fig. 4. Horizontal assemblage of all recorded pings (447 individual echoes) in (a) the cross-section of the echo beam during a $6 \mathrm{~min}$ ascent sequence for an individual target (framed by red in the echogram; b). $\mathrm{S}_{\mathrm{v}}$ threshold is $-85 \mathrm{~dB}$

valence of descending individuals over the course of the night (Figs. 3d \& 5). Mean ( \pm SD) step lengths and duration of pauses during descent were $0.98 \pm 0.39 \mathrm{~m}$ and $52 \pm 31 \mathrm{~s}$, respectively $\left(\mathrm{n}_{\text {tracks }}=42\right)$.
We furthermore tracked individuals $(\mathrm{n}=43)$ from the shallowest SL during their dawn ascent. These targets also migrated in a stepwise manner, with step lengths of $0.40 \pm 0.31 \mathrm{~m}$ and pauses of $36 \pm 27 \mathrm{~s}$. 


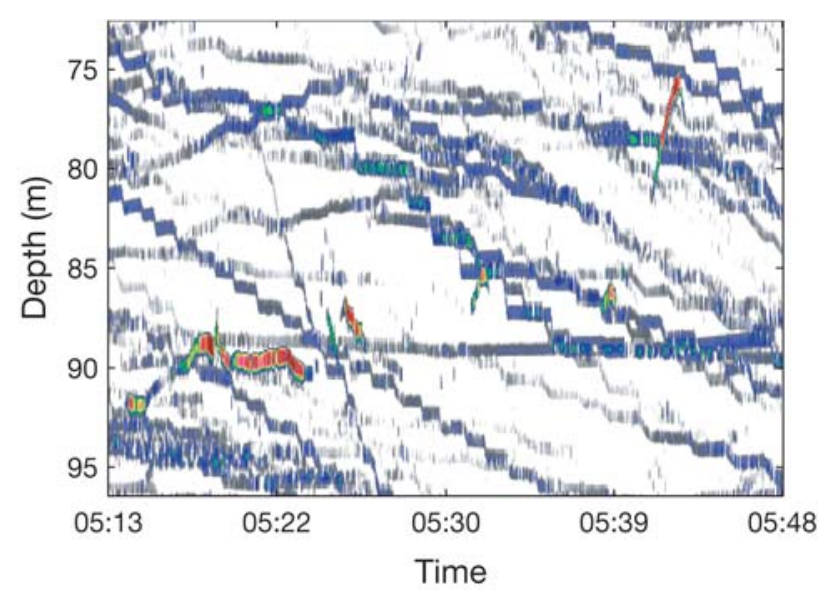

Fig. 5. Records at $38 \mathrm{kHz}$ from the hull-mounted transducer. Each echo trace represents 1 organism. $\mathrm{S}_{\mathrm{v}}$ threshold is $-85 \mathrm{~dB}$. Sunrise at 07:15 h. Time is GMT (local $-1 \mathrm{~h}$ )

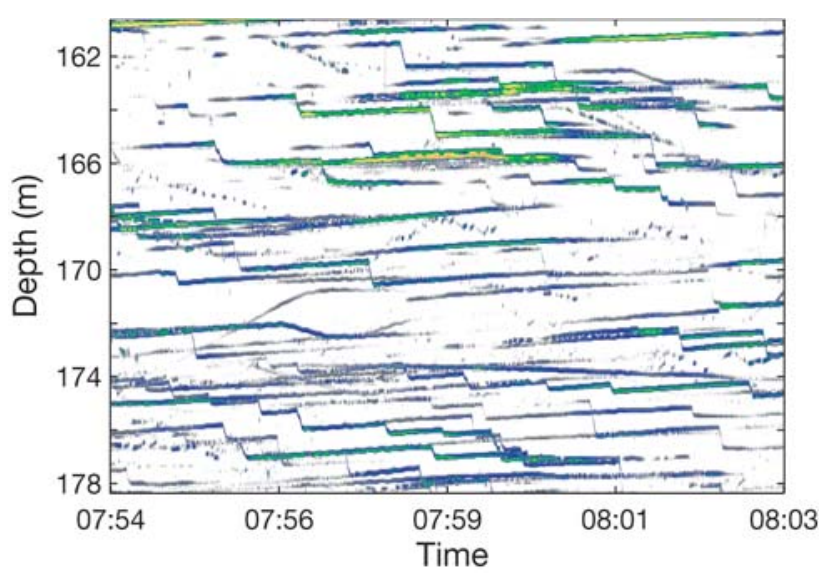

Fig. 6. Vertically migrating individuals recorded in the deep water of Sørfjorden in the morning $(120 \mathrm{kHz}$ echo sounder submerged at 150 m; depicted by \#4 in Fig. 2). Each stepwise descending echo trace represents 1 organism. $\mathrm{S}_{\mathrm{v}}$ threshold is $-85 \mathrm{~dB}$. Sunrise at 07:25 h. Time is GMT (local $-1 \mathrm{~h})$

\section{Sørfjorden}

In Sørfjorden, we focused on observations with the echo sounder submerged at $150 \mathrm{~m}$. Stepwise migrating organisms descended past this depth at dawn (Fig. 6) and ascended at dusk. Mean step lengths and duration of pauses during descent were $0.80 \pm 0.61 \mathrm{~m}$ and $69 \pm$ $47 \mathrm{~s}$, respectively $\left(\mathrm{n}_{\text {tracks }}=29\right)$, while only a few tracks were recorded during the ascent.

The results from the submerged echo sounder revealed that individuals in the deep SL were slowly 'floating' on internal waves of $\sim 10 \mathrm{~m}$ amplitude and periods of $2 \mathrm{~h}$ between peaks (Fig. 7a). The internal waves were depicted by individual targets that remained in the acoustic beam for prolonged periods.
They seemed to be largely non-moving, apart for infrequent, small shifts in vertical distribution, which appeared when observed at a finer vertical and temporal scale (Fig. 7b).

\section{DISCUSSION}

\section{Composition of scattering layers}

The upper SL contained Maurolicus muelleri. This SL can be identified by its vertical distribution and characteristics of the diel migration pattern, comprising ascent to surface waters for a short period at dusk, sinking out of the uppermost layer when becoming totally dark, and subsequent short-term dawn ascents in the morning (Giske et al. 1990, Baliño \& Aksnes 1993, Bagøien et al. 2001). Small M. muelleri (juve-

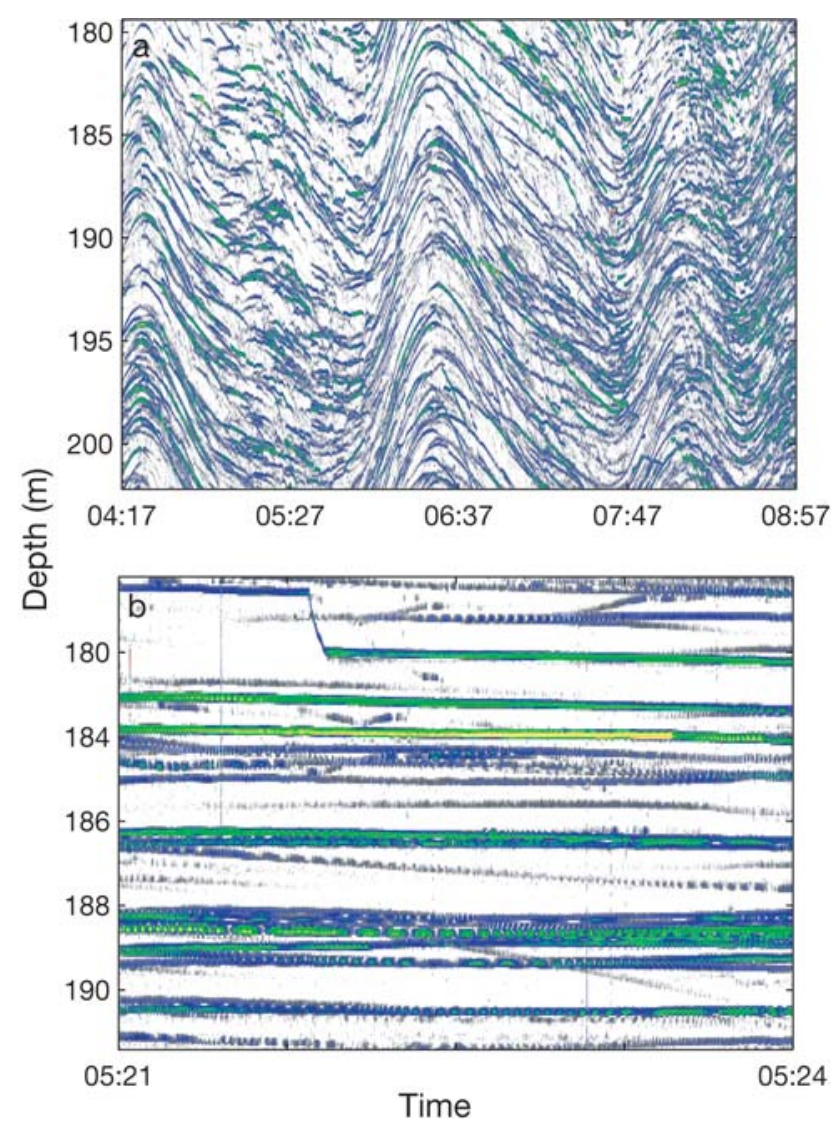

Fig. 7. Records from the submerged $120 \mathrm{kHz}$ echo sounder suspended at $150 \mathrm{~m}$ in Sørfjorden (echo sounder depicted by \#4 in Fig. 2). (a) A $4 \mathrm{~h} 40$ min registration period showing the mesopelagic fauna being slowly displaced vertically by internal waves; (b) a 3 min registration period showing that most individuals apparently remain stationary in the acoustic beam, though with an example of a small shift in vertical position. $\mathrm{S}_{\mathrm{v}}$ threshold is $-90 \mathrm{~dB}$ 
niles) were captured in the net tows from this SL in Sørfjorden.

Several taxa occurred in the layer below, but mesopelagic fish were the dominant acoustic targets. This is evident from the SL being strongly recorded even at $18 \mathrm{kHz}$; the non-resonating invertebrates would not contribute substantially at this frequency. Furthermore, the fact that stepwise migrating individuals were recorded even at a range of $\sim 100 \mathrm{~m}$ by the $38 \mathrm{kHz}$ echo sounder rules out the invertebrates. The relative occurrences of Maurolicus muelleri and Benthosema glaciale are uncertain due to the failure of sampling with a closing net, but previous studies have shown that adult $M$. muelleri prevails in acoustic SLs down to 150-200 m, while B. glaciale inhabits waters below that depth (Giske et al. 1990, Baliño \& Aksnes 1993, Bagøien et al. 2001). Results from the sampling in Sørfjorden were in concordance with such vertical distributions (cf. Fig. 1).

\section{Individual swimming behavior}

Stepwise vertical swimming behavior was recorded for fish in both the upper and lower part of the water column, which suggests that both species applied some variety of this migration pattern. This DVM behavior was very similar to schematic representations of stop-and-go search behavior, as outlined in O'Brien et al. (1990; our Fig. 8). They argued that the prey search patterns known as cruise (swimming continuously while foraging) and ambush (searching while stationary for extended periods) are extremes at the ends of a continuum where predators alternate between moving a short or long distance, and stopping to

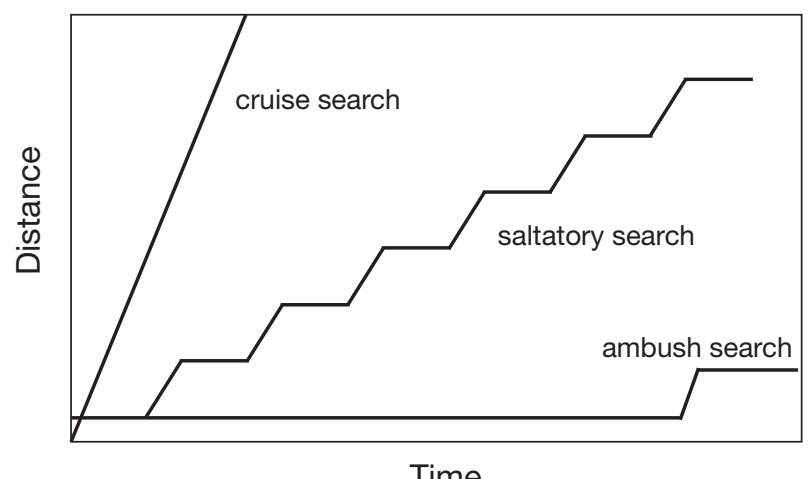

Fig. 8. Search strategies redrawn from O'Brien et al. (1990). According to this scenario, search strategies range from constant motion of cruising foragers to infrequent short relocations among ambushers. Most taxa display intermediate stopand-go 'saltatory' search behavior. In this pattern, pauses to search for prey alternate with repositioning for scanning of new territory search for a shorter or longer time. Such stop-and-go behavior is referred to as 'saltatory search', and is applied by many planktivorous fish and other predators. Patterns are species-specific, but duration of pauses and the speed and length of reposition moves can also vary within species, e.g. depending on size and visibility of prey (O'Brien et al. 1990).

Saltatory search also applies to nonvisual (mechanosensory) prey detection, and small planktivorous fish feeding in the dark may move in a stop-and-go fashion (Ryer \& Olla 1999). Prey apparently is more easily detected during the pause phase, when the hydromechanical signal-to-noise ratio is maximized (Janssen 1997, Ryer \& Olla 1999).

Foragers must divide their time between vigilance for predators and scanning for prey, and saltatory search may allow a balance between these demands. Predation risks are higher while moving than while stationary (O'Brien et al. 1990). Both Maurolicus muelleri and Benthosema glaciale are covered ventrally with photophores, apparently used for counterillumination (cf. Herring 1982), and tilting of the body during vertical repositioning will result in loss of camouflage. Janssen et al. (1986) observed that hatchet fishes were capable of migrating vertically without altering their body posture. They surmised that this was a means of maintaining protection against predation, also during vertical migrations. Stepwise migrations, with tilting restricted to short, intermittent periods, may represent an alternative solution.

Stepwise DVM patterns were also observed by Mehner (2006), who used an echo sounder in studies of freshwater fish. He ascribed the intermittent stops to pressure compensation of swimbladder volume. This explanation does not apply in our case. We recorded such behavior even at depths of $\sim 200 \mathrm{~m}$, where pressure differences related to small $(<1 \mathrm{~m})$ vertical steps are negligible. Furthermore, similar behavior was observed during both ascent and descent, whereas there is an asymmetry in absorption and secretion rates of swimbladder gases, which are absorbed much faster than they are secreted (Strand et al. 2005).

Diel migrating individuals remained in the acoustic beam for extended periods. This implies little net horizontal movement, which was also suggested by TT (Fig. 4). The negligible net horizontal movement during vertical migration can possibly be explained by circular swimming. Saltatory searchers can quickly move into unsearched areas by turning after pausing; planktivorous fish studied in laboratories turned after each unsuccessful search (O'Brien et al. 1990). Such swimming patterns have been reported for lanternfish observed from submersibles. Barham (1966) stated that during the morning descent, individual fish 'paused momentarily, changed direction, and continued down- 
ward'. In the present study, use of a freely suspended transducer prevented us from drawing conclusions about small-scale swimming in the horizontal plane since any movement of the transducer might corrupt data on swimming paths. In the future, such questions can be addressed using TT on data from upwardfacing, bottom-mounted (i.e. completely stable) transducers.

\section{Records in deep water}

Some of the deep-dwelling $(>\sim 150 \mathrm{~m}$ ) targets carried out DVM. Otherwise, individuals constituting the deep SLs seemed to be conspicuously inactive both day and night, as suggested from long-lasting echo traces (i.e. long residence time in the acoustic beam). Circular swimming might also result in long-lasting echo traces, previously shown for krill (Klevjer \& Kaartvedt 2006), but inactivity would be in accordance with previous observations from submersibles of midwater fish commonly hanging motionless in the water column (Backus et al. 1968, Barham 1970). The deepliving individuals were passively displaced in the vertical by slow internal waves (vertical velocities of $\sim 3 \mathrm{~mm} \mathrm{~s}^{-1}$ ). If foraging, the long duration of the pause phases in their trajectories, followed by infrequent, small shifts in vertical position, reflect the schematic presentation of ambush feeders (cf. Figs. 7b \& 8).

This study has shown that acoustic techniques can provide detailed information on in situ behavior of mesopelagic organisms. We advocate that calm and low-advection fjord environments can be used as ocean models to assess behavior and trophic interactions of mesopelagic organisms.

\section{LITERATURE CITED}

Anderson CIH, Brierley AS, Armstrong F (2005) Spatiotemporal variability in the distribution of epi- and mesopelagic acoustic backscatter in the Irminger Sea, North Atlantic, with implications for predation on Calanus finmarchicus. Mar Biol 146:1177-1188

Auster PJ, Griswold CA, Youngbluth MJ, Bailey TG (1992) Aggregations of myctophid fishes with other pelagic fauna. Environ Biol Fishes 35:133-139

Backus RH, Craddock JE, Haedrich RL, Shores DL and others (1968) Ceratoscopelus maderensis: peculiar soundscattering layer identified with this myctophid fish. Science 160:991-993

Bagøien E, Kaartvedt S, Aksnes DL, Eiane K (2001) Vertical distribution and mortality of overwintering Calanus. Limnol Oceanogr 46:1494-1510

Baliño BM, Aksnes DL (1993) Winter distribution and migration of the sound scattering layers, zooplankton and micronekton in Masfjorden, western Norway. Mar Ecol Prog Ser 102:35-50

Balk H, Lindem T (2000) Improved fish detection in data from split-beam sonar. Aquat Living Resour 13:297-303

Balk H, Lindem T (2002) Sonar4 and Sonar5-Pro post processing systems. Operator manual. Lindem Data Acquisition, Oslo

Barham EG (1966) Deep scattering layer migration and composition: observations from a diving saucer. Science 151:1399-1403

Barham EG (1970) Deep-sea fishes: lethargy and vertical orientation. In: Farquhar GB (ed) Proc Int Symp Biol Sound Scattering in the Ocean, Warrenton, Virginia, March 31-April 02, 1970. Ocean Science Program, Washington, DC, p 100-118

> Benoit-Bird KJ (2004) Prey caloric value and predator energy needs: foraging predictions for wild spinner dolphins. Mar Biol 145:435-444

> Dale T, Bagøien E, Melle W, Kaartvedt S (1999) Can predator avoidance explain varying overwintering depth of Calanus in different oceanic water masses? Mar Ecol Prog Ser 179:113-121

> Ehrenberg JE, Torkelson TC (1996) Application of dual-beam and split-beam target tracking in fisheries acoustics. ICES J Mar Sci 53:329-334

Garrison T (2005) Oceanography. Thomson Brooks/Cole, Belmont, CA

Gerritsen J, Strickler JR (1977) Encounter probabilities and community structure in zooplankton: a mathematical model. J Fish Res Board Can 34:73-82

Giske J, Aksnes DL, Baliño BM, Kaartvedt S and others (1990) Vertical distribution and trophic interactions of zooplankton and fish in Masfjorden, Norway. Sarsia 75:65-81

Herring PJ (1982) Aspects of the bioluminescence of fishes. Oceanogr Mar Biol Annu Rev 20:415-470

Hopkins TL, Sutton TT (1998) Midwater fishes and shrimps as competitors in low latitude oligotrophic ecosystems. Mar Ecol Prog Ser 164:37-45

Janssen J (1997) Comparison of response distance to prey via the lateral line in the ruffle and yellow perch. J Fish Biol 51:921-930

Janssen J, Harbison GR, Craddock JE (1986) Hatchetfishes hold horizontal attitudes during diagonal descents. J Mar Biol Assoc UK 66:825-833

Kaartvedt S (2000) Life history of Calanus finmarchicus in the Norwegian Sea in relation to planktivorous fish. ICES J Mar Sci 57:1819-1824

> Kaartvedt S, Aksnes DL, Aadnesen A (1988) Winter distribution of macroplankton and micronekton in Masfjorden, Western Norway. Mar Ecol Prog Ser 45:45-55

$>$ Klevjer TA, Kaartvedt S (2003) Split-beam target tracking can be used to study the swimming behavior of deep-living plankton in situ. Aquat Living Resour 16:293-298

Klevjer TA, Kaartvedt S (2006) In situ target strength and behaviour of northern krill (Meganyctiphanes norvegica). ICES J Mar Sci 63:1726-1735

Love RH, Fisher RA, Wilson MA, Nero RW (2004) Unusual swimbladder behavior of fish in the Cariaco Trench. DeepSea Res I 51:1-16

> Mehner T (2006) Individual variability of diel vertical migrations in European Vendace (Coregonus albula) explored by stationary vertical hydroacoustics. Ecol Freshw Fish 15:146-153

> Munk P, Larsson PO, Danielsen DS, Moksness E (1995) Larval and small juvenile cod Gadus morhua concentrated in the highly productive areas of a shelf break front. Mar Ecol Prog Ser 125:21-30

O'Brien WJ, Browman HI, Evans BI (1990) Search strategies of foraging animals. Am Sci 78:152-160

Onsrud MSR, Kaartvedt S, Breien MT (2005) In situ swim- 
ming speed and swimming behaviour of fish feeding on the krill Meganyctiphanes norvegica. Can J Fish Aquat Sci 62:1822-1832

Pearre S (2003) Eat and run? The hunger/satiation hypothesis in vertical migration: history, evidence and consequences. Biol Rev Camb Philos Soc 78:1-79

Robison BH (2004) Deep pelagic ecology. J Exp Mar Biol Ecol 300:253-272

Ryer CH, Olla BL (1999) Light-induced changes in the prey consumption and behavior of two juvenile planktivorous fish. Mar Ecol Prog Ser 181:41-51

Initial editorial responsibility: Howard Browman, Storebø, Norway (until November 5, 2007); Final editorial responsibility: Matthias Seaman, Oldendorf/Luhe, Germany
Skjoldal HR (ed) (2004) The Norwegian Sea ecosystem. Tapir Academic Press, Trondheim

Smith S, Roman M, Prusova I, Wishner K and others (1998) Seasonal response of zooplankton to monsoonal reversals in the Arabian Sea. Deep-Sea Res II 45:2369-2403

Strand E, Jørgensen C, Huse G (2005) Modelling buoyancy regulation in fishes with swimbladders: bioenergetics and behaviour. Ecol Modell 185:309-327

Torgersen T, Kaartvedt S (2001) In situ swimming behaviour of individual mesopelagic fish studied by split-beam echo target tracking. ICES J Mar Sci 58:346-354

Submitted: August 25, 2006; Accepted: November 29, 2007 Proofs received from author(s): May 14, 2008 